\title{
Corrections by melatonin of liver mitochondrial disorders under diabetes and acute intoxication in rats
}

\author{
Vitali T. Cheshchevik ${ }^{1}$, Iosif K. Dremza ${ }^{1}$, Elena A. Lapshina ${ }^{1}$, Svetlana V. Zabrodskaya', Jolanta Kujawa ${ }^{3}$ and \\ Ilya B. Zavodnik ${ }^{1,2} *$ \\ 'Institute for Pharmacology and Biochemistry, National Academy of Sciences of Belarus, Grodno, Belarus \\ ${ }^{2}$ Depe tment of Biochemistry, Yanka Kupala State University, Grodno, Belarus \\ ${ }^{3}$ Department of Rehabilitation, Medical University of Lodz, Lodz, Poland
}

The aim of the present work was to investigate the mechanisms of oxidative damage of the liver mitochondria under diabetes and intoxication in rats as well as to evaluate the possibility of corrections of mitochondrial disorders by pharmacological doses of melatonin. The experimental ( 30 days) streptozotocin-induced diabetes mellitus caused a significant damage of the respiratory activity in rat liver mitochondria. In the case of succinate as a respiratory substrate, the ADP-stimulated respiration rate $V_{3}$ considerably decreased (by $25 \%$, $p<0.05$ ) as well as the acceptor control ratio (ACR) $V_{3} / V_{2}$ markedly diminished (by $25 \%, p<0.01$ ). We observed a decrease of the ADP-stimulated respiration rate $\mathrm{V}_{3}$ by $35 \%(p<0.05)$, with glutamate as substrate. In this case, ACR also decreased (by $\left.20 \%, p<0.05\right)$. Surprisingly, the phosphorylation coefficient ADP/O did not change under diabetic liver damage. Acute rat carbon tetrachloride-induced intoxication resulted in considerable decrease of the phosphorylation coefficient because of uncoupling of the oxidation and phosphorylation processes in the liver mitochondria. The melatonin administration during diabetes $\left(10 \mathrm{mg} \cdot \mathrm{kg}^{-1}\right.$ body weight, 30 days, daily) showed a considerable protective effect on the liver mitochondrial function, reversing the decreased respiration rate $\mathrm{V}_{3}$ and the diminished $A C R$ to the control values both for succinate-dependent respiration and for glutamate-dependent respiration. The melatonin administration to intoxicated animals ( $10 \mathrm{mg} \cdot \mathrm{kg}^{-1}$ body weight, three times) partially increased the rate of succinate-dependent respiration coupled with phosphorylation. The impairment of mitochondrial respiratory plays a key role in the development of liver injury under diabetes and intoxication. Melatonin might be considered as an effector that regulates the mitochondrial function under diabetes. Copyright (1) 2011 John Wiley \& Sons, Ltd.

KEY wORDS-Inelatonin; rat liver mitochondria; respiration; diabetes; oxidative stress

\section{INTRODUCTION}

Mitochondria play a key role in coordination of the main cellular functions. They provide energy required for all cellular processes as well as participate in cell signalling and in necrotic and apoptotic cell death. There is evidence that defective mitochondrial oxidative phosphorylation plays an important role in the pathogenesis of many diseases: Alzheimer's disease, diabetes, and ageing. ${ }^{10}$ Mitochondria are major producers of free radical species in the cell (possibly also nitric oxide) and are major targets of oxidative damage. ${ }^{8}$ The mitochondrial function is particularly susceptible to oxidative stress, leading to decreased mitochondrial adenosine-5'-triphosphate (ATP) synthesis, cellular calcium dyshomeostasis and induction of mitochondrial permeability transition, all of which predispose cells to necrosis or apoptosis. ${ }^{11,13}$

The main consequences of hyperglyccmia of particularly pathological relevance in diabetes are as follows: formation,

* Correspondence to: I. B. Zavodnik, Department of Biochemistry, Yanka Kupala State University, Grodno, Belarus. E-mail: zavodnik_il@mail.ru auto-oxidation and interaction with cell receptors of advanced glycation end products, protein glycation, protein kinase $\mathrm{C}$ activation and induction of the polyol pathway, as well as increased hexosamine pathway flux. ${ }^{30}$ Many of these pathways have long been associated with oxidative stress. ${ }^{30}$ Much of the hyperglycemia-related damages under both types 1 and 2 diabetes are suggested to be a consequence of elevated production of reactive oxygen species by the mitochondrial respiratory chain and mitochondrial oxidative damage. ${ }^{30}$ Similarly, mitochondrial dysfunction is an early manifestation of hepatotoxic agent effects. The metabolic capacity of liver mitochondria is considerably impaired in rats with carbon tetrachlorideinduced cirrhosis caused by both reduced mitochondria volume per liver and damaged metabolism of the remaining mitochondria. ${ }^{15}$ Reduced oxygen consumption and mitochondrial enzyme activities as well as a diminished rate of ATP production were observed under intoxication. ${ }^{15}$

Melatonin (N-acetyl-5-methoxy-tryptamine) has a number of membrane-bound receptor-mediated actions, including regulation of circadian rhythms, reproduction, immunoregulation and retinal function. ${ }^{3,5}$ Melatonin has 
been shown to be an effective antioxidant in a number of experimental models both in vitro and in vivo.,35,38 The antioxidative effects of melatonin range from direct radical scavenging to modulation of a number of processes, which may trigger a redox balance in the cell. ${ }^{3,19,23,29}$ At the molecular level, melatonin has effects that optimize cellular functions (mitochondrial respiration, ATP production, gene transcription and translation, and protein synthesis). ${ }^{5}$ The mitow. wondria-modulating effect of melatonin may account for some of the protective properties of indolamine and may be of physiological significance because it seems that the indolamine is concentrated into the mitochondria., 1,22 Pharmacological corrections of mitochondrial activity and cell bioenergetics and prevention of the mitochondrial oxidative damage are a beneficial therapeutic approach in many pathological states, such as diabetes, which are connected with mitochondrial dysfunctions. Mitochondriatargeted antioxidants are to have a therapeutic potential in diabetes. " At the same time, despite the prevalence of mitochondrial dysfunction in many diseases, mitochondria-specific therapies have not been well developed. ${ }^{34}$ Correction of the mitochondrial functions is the basis of 'mitochondrial medicine' 10

Despite the fact that hepatic lesions under intoxication and diabetes are well characterized by biochemical, morphological and histochemical studies, the early events critical to the onset of toxic and diabetic hepatocyte impairments remain unclear. The aim of this study was to examine the liver nitochondria respiratory parameters under diabetes in rats. The corrections of mitochondrial disorders by pharmacological doses of melatonin were simultaneously evaluated. The effects of diabetes on rat liver mitochondrial functional activity were compared with those of rat intoxication, and the beneficial effect of melatonin under diabetes was compared with that under acute intoxication.

\section{MATERIALS AND METHODS}

\section{Chemicals}

Melatonin, carbon tetrachloride $\left(\mathrm{CCl}_{4}\right), 5,5^{\prime}$-dithiobis (2-nitrobenzoic acid) (Ellman's reagent), reduced glutathione (GSH), safranin O and trichloroacetic acid were from SigmaAldrich, St. Louis, MO. Streptozotocin (streptozocin; STZ) was from Fluka Chemie AG, Buchs, Switzerland. All other reagents were of analytical grade and were purchased from Reakhim. Moscow, Russia. All the solutions were made with water purified in the Milli-Q system.

\section{Animal nodels}

The investigations were performed using 80 male albino Wistar rats $(150-180 \mathrm{~g})$. A standard balanced diet and tap water were provided ad libitum. The animals were adapted to an intermittent 12-h light and dark phases cycle for 1 week and were clivided into two groups for $\mathrm{CCl}_{4}$ intoxication and experimental model of diabetes. Lights were on daily from 08:00 to $20: 00 \mathrm{~h}$.
Diabetes. Ten animals received physiological saline containing 5\% ethanol intraperitoneally (i.p.) and were kept as controls. Thirty animals were injected with a single dose of STZ ( $45 \mathrm{mg} \cdot \mathrm{kg}^{-1}$, i.p.), dissolved in $0.01 \mathrm{M}$ citrate buffer, $\mathrm{pH}$ 4.5, immediately before use. Seven days later. blood glucose levels were determined in whole blood samples. The rats injected with STZ were considered diabetic if their fasting blood glucose was $>200 \mathrm{mg} \cdot \mathrm{dL}^{-1}$ (Blood Glucose Sensor Electrodes, MediSense; Abbot Laboratories, Bedford, UK). All the animals diagnosed as diabetic were further divided into two subgroups: the first subgroup was injected daily with physiological saline containing 5\% ethanol (i.p.) (the group 'diabetes'), and the second subgroup received daily $10 \mathrm{mg} \cdot \mathrm{kg}^{-1}$ body weight of melatonin (i.p.) ('diabetes $+10 \mathrm{mg}$ melatonin'). Melatonin was prepared as a $0.3 \%$ solution in the physiological saline, containing $5 \%$ ethanol and injected at 08:00h. Melatonin was injected in the morning (not before nocturnal increase of the physiological melatonin level) because we evaluated nonspecific antioxidative effect of melatonin. The dose of melatonin was chosen on the bases of previous studies. ${ }^{22,27}$ The experiment (melatonin treatment) began 7 days after the STZ injection, and the rats were sacrificed after 30 days of melatonin (or saline) administration.

$\mathrm{CCl}_{4}$ intoxication. The animals were subdivided into four subgroups: (1) control animals treated only with olive oil $\left(5 \mathrm{ml} \cdot \mathrm{kg}^{-1}\right.$, intragastrically, i.g.) and ethanol $(5 \%$, i.p. $)$ in the same volume as the inelatonin solution; (2) treated with i.p. melatonin and i.g. olive oil; (3) treated with the 5\% ethanol solution and $\mathrm{CCl}_{4}$; and (4) treated with melatonin and $\mathrm{CCl}_{4}$. $\mathrm{CCl}_{4}$ was administered i.g. at a dose of $4 \mathrm{~g} \cdot \mathrm{kg}^{-1}$ body weight $\left(2.5 \mathrm{ml} \cdot \mathrm{kg}^{-1}\right)$ in a $50 \%$ olive oil solution at $9 \mathrm{~h}$, and the rats were decapitated on the following day at $9 \mathrm{~h}$. Melatonin (10 $\mathrm{mg} \cdot \mathrm{kg}^{-1}$ body weight) was injected three times: at $30 \mathrm{~min}$ before and then 2 and $6 \mathrm{~h}$ after the $\mathrm{CCl}_{4}$ administration. The rats fasted for $24 \mathrm{~h}$ before $\mathrm{CCl}_{4}$ treatment, but they received water ad libitum. Hepatic toxicity of $\mathrm{CCl}_{4}$ was estimated by means of biochemical measurements and analysis of mitochondrial respiration activity.

The animals were killed by decapitation according to the rules defined by the European Convention for the Protection of Vertebrate Animals Used for Experimental and Other Scientific Purposes.

Blood samples were drawn by an abdominal aorta puncture into tubes containing hirudin $\left(50 \mu \mathrm{g} \cdot \mathrm{ml}^{-1}\right)$. After the removal of plasma by centrifugation, the erythrocytes were washed three times with cold PBS, pH 7.4, and haemolysed.

\section{Isolation of rat liver mitochondria}

Mitochondria were isolated by differential centrifugation from the liver. ${ }^{14}$ The liver was quickly removed and placed into the ice-cold isolation medium containing $250 \mathrm{mmol} \cdot \mathrm{l}^{-1}$ of sucrose, $20 \mathrm{mmol} \cdot \mathrm{l}^{-1}$ of Tris- $\mathrm{HCl}$ and $1 \mathrm{mmol} \cdot \mathrm{l}^{-1}$ of EDTA, pH 7.2. The tissue was cut into small pieces and homogenized in a glass-Teffon homogenizer with isolation 
medium (at $2^{\circ} \mathrm{C}$ ). The homogenate was centrifuged at $600 \mathrm{~g}$ for $10 \mathrm{~min}$, and the supernatant was centrifuged at $8500 \mathrm{~g}$ for $:$ min. The obtained pellet was washed in buffer containing $250 \mathrm{mmol} \cdot \mathrm{I}^{-1}$ of sucrose and $5 \mathrm{mmol} \cdot \mathrm{I}^{-1}$ of Tris$\mathrm{HCl}, \mathrm{pH} 7.2$ (at $2^{\circ} \mathrm{C}$ ). The final centrifugation was carried out at $8500 \mathrm{~g}$ for $10 \mathrm{~min}$. The mitochondrial pellet was resuspended in the buffer to an approximate protein concentration of $35-40 \mathrm{mg} \cdot \mathrm{ml}^{-1}$. The protein concentration was determined by the method of Lowry et al.. ${ }^{18}$

The respiration of mitochondria was measured using a laboratory-made oxygen Clark-type electrode and a hermetic polarographic cell (volume $1.25 \mathrm{ml}$ ) with constant gentle stirring. ${ }^{7}$ The electrode was calibrated by bubbling the polarographic cell with pure nitrogen $\left(\mathrm{pO}_{2}=0\right)$ and atmospheric air (atmospheric $\mathrm{pO}_{2}$ ). The oxygen consumption by the electrode was negligible. The incubation medium contained $125 \mathrm{mmol} \cdot \mathrm{l}^{-1}$ of sucrose, $20 \mathrm{mmol} \cdot \mathrm{l}^{-1}$ of Tris- $\mathrm{HCl}$, $50 \mathrm{mmol} \cdot \mathrm{l}^{-1}$ of $\mathrm{KCl}, 20 \mathrm{mmol} \cdot \mathrm{l}^{-1}$ of $\mathrm{KH}_{2} \mathrm{PO}_{4}, 5 \mathrm{mmol} \cdot \mathrm{l}^{-1}$ of $\mathrm{MgSO}_{4}$ and $1 \mathrm{mmol} \cdot \mathrm{l}^{-1}$ of EDTA, $\mathrm{pH} 7 \cdot 5$. The experiments were performed at $26 \cdot 5^{\circ} \mathrm{C}$ using $5 \mathrm{mmol} \cdot \mathrm{l}^{-1}$ of succinate or 4 $\mathrm{mmol} \cdot \mathrm{l}^{-1}$ of $\mathrm{L}$-glutamate as substrates. Mitochondrial protein concentration in the probe was $1.0 \mathrm{mg} \cdot \mathrm{ml}^{-1}$. The functional state 'f the mitochondria was determined by the acceptor control ratio (ACR), equal to the ratio of the respiratory rates $\left(V_{3} / V_{2}\right)$ of the mitochondria in States 3 and 2; by the respiratory control ratio ( $R C R$ ), equal to the ratio of the respiratory rates $\left(V_{3} / V_{4}\right)$ of the mitochondria in States 3 and 4 ; and by the coefficient of phosphorylation (ADP/O), according to the common terminology. ${ }^{6}$ The rate of mitochondrial respiration corresponding to State $3\left(\mathrm{~V}_{3}\right)$ was registered after addition of $180 \mu \mathrm{mol} \cdot \mathrm{l}^{-1}$ of $\mathrm{ADP}$ (in the presence of $210 \mathrm{~nm}$ of ADP in the polarographic cell). State 1 corresponded to the respiration in the presence of endogenous substrates $\left(V_{1}\right)$, State 2 corresponded to the respiration in the presence of substrate (glutamate or succinate) added $\left(\mathrm{V}_{2}\right)$ and State 4 corresponded to the respiration when the ADP added was exhausted $\left(\mathrm{V}_{4}\right)$.

\section{Mitochondrial transmembrane potential}

Mitochondrial transmembrane potential $(\Delta \psi)$ was measured in the medium $\left(200 \mathrm{mmol} \cdot \mathrm{l}^{-1}\right.$ of sucrose, $20 \mathrm{mmol} \cdot \mathrm{l}^{-1}$ of Tris$\mathrm{HCl}, 2.5 \mathrm{mmol} \cdot \mathrm{l}^{-1}$ of $\mathrm{MgSO}_{4}, 2.5 \mathrm{mmol} \cdot 1^{-1}$ of $\mathrm{KH}_{2} \mathrm{PO}_{4}, 20$ $\mathrm{mmol} \cdot 1^{-1}$ of $\mathrm{KCl}$, and $1 \mathrm{mmol}^{-1}$ of EDTA, $\mathrm{pH} 7.2$ ) at $27^{\circ} \mathrm{C}$ using fluorescence of the cationic dye safranin $\mathrm{O}$ that is accumulated and quenched inside the energized mitochondria. The excitation wavelength was $495 \mathrm{~nm}$ (slit $3 \mathrm{~nm}$ ), and the emission wavelength was $586 \mathrm{~nm}$ (slit $3 \mathrm{~nm}$ ) [an SM 2203 spectrofluorimeter (Solar, Belarus)]; the dye concentration used was $8 \mu \mathrm{mol} \cdot \mathrm{l}^{-1},{ }^{2}$ and the mitochondrial protein concentration was $0.3 \mathrm{mg} \cdot \mathrm{ml}^{-1}$. For mitochondrial membrane depolarization. we used the uncoupler, 2,4-dinitrophenol $\left(36 \mu \mathrm{mol} \cdot \mathrm{l}^{-1}\right)$, in the presence of $\mathrm{NaN}_{3}\left(5 \mathrm{mmol} \cdot \mathrm{l}^{-1}\right)$ as inhibitor of the respiratory chain. The membrane potential was determined using a calibration plot, ${ }^{24}$ which represents the dependence of the fluorescence intensity of safranin $\mathrm{O}$ on the membrane potential value, according to the Nernst equation:

$$
\Delta \Psi=60 \log \left[\mathrm{K}^{+}\right]_{\text {out }} /\left[\mathrm{K}^{+}\right]_{\text {in }}(\mathrm{mV}),
$$

where the $\left[\mathrm{K}^{+}\right]_{\text {in }}$ is the intramitochondrial potassium concentration $\left(120 \mathrm{mmol} \cdot \mathrm{l}^{-1}\right),{ }^{2}$ and the $\left[\mathrm{K}^{+}\right]_{\text {out }}$ is the extramitochondrial potassium concentration in the media that varies from 0 to $20 \mathrm{mmol} \cdot \mathrm{l}^{-1}$ in the presence of ionophore valinomycine $\left(0.28 \mu \mathrm{mol} \cdot \mathrm{I}^{-1}\right)$. We used succinate and $\alpha$-ketoglutarate as substrates for potential generation.

\section{Biochemical measurements}

A stable form of glycated haemoglobin containing 1-deoxy$1(\mathrm{~N}$-valyl)fructose and blood plasma urea were assayed using a reagent set (Pliva-Lachema a.s., Brno, Czech Republic). The concentration of nonprotein thiols (predominantly, of GSH in mitochondria was determined spectrophotometrically by the method of Ellman ${ }^{9}$ using the molar absorption coefficient $\varepsilon_{412}=1 \cdot 36 \cdot 10^{4} \mathrm{M}^{-1} \cdot \mathrm{cm}^{-1}$. Mixed disulfides (GSSP) formed by glutathione and accessible sulfhydryl groups of mitochondrial proteins were determined by the method described by Rossi et al.. ${ }^{32}$

\section{Statistical analysis}

Data for 8-10 rats in each group are presented as a mean \pm SD for the normally distributed parameters or as a median and interquartile range for the data showing departures from normality. We used the standard Student's $t$-test for the comparison of the raw and transformed data showing no departures from normality (according to Shapiro-Wilk's test) and the nonparametric Mann-Whitney $U$-test for the remaining variables. $p<0.05$ was taken to indicate statistical significance.

\section{RESULTS}

After 30 days of diabetes in rats, we observed the typical signs of hyperglycemia: a high glycosylated haemoglobin level and animal growth retardation (Table 1). The melatonin administration showed a slight hypoglycemic effect and some reduction of the glycosylated haemoglobin level. We observed a statistically significant increase of the rat blood urea under diabetes (by $40 \%, p<0.05$ ) as a result

Table 1. Blood glucose and urea, glycated haemoglobin and body weight in nontreated and melatonin-treated STZ-diabetic rats

\begin{tabular}{|c|c|c|c|c|}
\hline $\begin{array}{l}\text { Animal } \\
\text { groups }\end{array}$ & $\begin{array}{l}\text { Blood } \\
\text { glucose, } \\
\left(\mathrm{mg} \cdot \mathrm{dl}^{-1}\right)\end{array}$ & $\begin{array}{l}\text { Body } \\
\text { weight (final- } \\
\text { initial), (g) }\end{array}$ & $\begin{array}{c}\text { Glycated } \\
\text { haemoglobin, } \\
\text { (mol tructose/g } \mathrm{Hb} \text { ) }\end{array}$ & $\begin{array}{l}\text { Blood urea, } \\
\left(\mathrm{mmol} \mathrm{l}^{-1}\right)\end{array}$ \\
\hline Control & $105 \cdot 3=5.9$ & 35 & $2.7 \pm 0.6$ & $7 \cdot 7 \pm 2 \cdot 2$ \\
\hline Diabetes & $522 \cdot 7=179 \cdot 4$ & 8 & $6 \cdot 1 \pm 0 \cdot 6^{*}$ & $10 \cdot 8 \pm 3.4^{\text {* }}$ \\
\hline $\begin{array}{l}\text { Diabetes + } \\
\text { melatonin }\end{array}$ & $405 \cdot 3 \pm 147 \cdot 8$ & 24.2 & $4.8 \pm 1.7$ & $10 \cdot 8 \pm 2 \cdot 8^{*}$ \\
\hline
\end{tabular}

Data, presented as a mean $\pm S D$, represent values at the termination of the experiment ( 30 days of experimental diabetes).

* $p<0.05$ versus control nontreated animals. 
of an increase in protein catabolism, amino acid deamination and urea synthesis activation. The melatonin administration did not prevent this process. It was postulated that the mitochondrial ROS production and consequent mitochondrial oxidative damage might contribute to the onset, progression and pathological consequences of types 1 and 2 diabetes. " The experimental (30-days) STZ-induced diabetes mellitus resulted in a considerable damage of the respiratory activity in rat liver mitochondria (Tables 2 and 3 ). The basal (endogenous) respiration rate $V_{1}$ decreased by $15-20 \%$. In the case of succinate as a respiratory substrate, the rate of oxygen consumption $V_{2}$ and the respiration rate $\mathrm{V}_{4}$ after ADP consumption did not change, but the ADPstimulated respiration rate $\mathrm{V}_{3}$ considerably decreased (by $25 \%, p<0.05)$ as well as the ACR $\mathrm{V}_{3} / \mathrm{V}_{2}$ and the RCR $\mathrm{V}_{3} /$ $\mathrm{V}_{4}$ markedly diminished (by $25 \%, p<0.01$, and by $27 \%$, $p<C ; 1$, respectively). Similarly, we observed a decrease of the respiration rate $V_{2}$ by $20 \%$ and the ADP-stimulated respiration rate $V_{3}$ by $35 \%(p<0.05)$ with glutamate as substrate, with no changes in the respiration rate $V_{4}$ being noticed. In this case, the ACR and the RCR also decreased (by $20 \%, p<0.05$, and $25 \%, p<0.01$, respectively). Surprisingly, the phosphorylation coefficient ADP/O did not change under diabetic liver damage. Therefore, the efficacy of oxygen consumption remained unchanged despite the respiration chain impairments. The melatonin administration during diabetes $\left(10 \mathrm{mg} \cdot \mathrm{kg}^{-1}\right.$ body weight, 30 days daily) exerted a considerable protective effect on the liver mitochondria function, reversing the decreased respiration rate $V_{3}$ to the control values both for succinate-dependent respiration $(p<0.05$ in comparison with diabetic animals) and for glutamate-dependent respiration $(p<0.01)$. Similarly, the melatonin treatment of diabetic rats reversed the effect of diabetes on the ACR and RCR values both for succinate-dependent respiration and for glutamate-dependent respiration (Tab's 2 and 3).

Figure 1 represents the fluorescence intensity dependence of the potential-sensitive dye safranin $O$ incorporated into the mitochondria on the mitochondrial potential (negative inside) that is used as a calibration curve. The mitochondrial Donnane potential calculated from this curve was equal to
$45 \mathrm{mV}$. Using this dependence and the intensity of safranin $O$ fluorescence in the liver mitochondria of diabetic and control animals, we calculated the values of the mitochondrial potential (Figure 2). When we used L-glutamate or $\alpha$ ketoglutarate as substrates, the membrane potential was generated by electron flow through complexes I, III and IV of the respiratory chain. When mitochondria oxidized succinate in the presence of rotenone, the membrane potential was generated by electron flow through complexes II, III and IV. As seen from Figure 2, despite the changes in the rates of mitochondrial oxygen consumption, we did not observe any significant alterations in the mitochondrial membrane potential under diabetes and melatonin treatment. The treatment of diabetic animals, not control animals, with melatonin slightly increased the membrane potential (by $15 \%$ in comparison with control animals) in the mitochondria oxidizing succinate rather than $\alpha$-ketoglutarate (Figure 2).

We did not observe marked changes in the mitochondrial GSH level and GSSP level under diabetes (Figure 3). In our experiments, the level of mixed protein-glutathione disulfides in rat liver mitochondria was $0.12 \pm 0.025 \mathrm{nmol} \cdot \mathrm{mg}^{-1}$ protein; it was about $1 \%$ from the mitochondrial GSH content. The melatonin administration had no effect on the GSH content in the liver mitochondria.

The effects of diabetes and melatonin administration on mitochondrial functional activity were compared with those of $\mathrm{CCl}_{4}$-induced rat intoxication and melatonin treatment. Tables 4 and 5 represent the parameters of liver mitochondria respiration for control, intoxicated and melatonintreated animals. After $24 \mathrm{~h}$ of acute $\mathrm{CCl}_{4}$ intoxication, we observed considerable mitochondrial dysfunction. The endogenous respiration rate $\left(\mathrm{V}_{1}\right)$ decreased by $30 \%$, the succinate-dependent respiration rate and the glutamatedependent respiration rate coupling with phosphorylation $\left(\mathrm{V}_{3}\right)$ markedly reduced (by $65 \%, p<0.0001$, and by $50 \%$, $p<0.01$, respectively (Tables 4 and 5). Under intoxication, the ACR and the RCR approached I, reflecting the luss of respiration control. The coefficient of phosphorylation significantly decreased, demonstrating a considerable reduction of the efficacy of oxygen consumption by the mitochondria under intoxication. Under intoxication, the membrane potential slightly decreased (by 12\%) for glutamate-dependent,

Table 2. Parameters of oxidative phosphorylation processes in rat liver mitochondria oxidizing succinate under STZ-induced diabetes (30days). Effect of melatonin administration ( $10 \mathrm{mg} \cdot \mathrm{kg}^{-1}$ body weight, 30 days daily).

\begin{tabular}{|c|c|c|c|c|c|c|c|}
\hline & $\begin{array}{c}\text { Basal respiration } \\
\text { rate } V_{1} \text {, (ng atom } \\
U / m i n)\end{array}$ & $\begin{array}{l}\text { Substrate-dependent } \\
\text { respiration rate } \mathrm{V}_{2} \text {, } \\
\text { (ng atom O/min) }\end{array}$ & $\begin{array}{l}\text { ADP-stimulated } \\
\text { respiration rate } \mathrm{V}_{3} \text {, } \\
\text { (ng atom } \mathrm{O} / \mathrm{min} \text { ) }\end{array}$ & $\begin{array}{c}\text { Respiration rate } \\
\text { after } A D P \text {-consumption } \\
\mathrm{V}_{4} \text {, (ng atom O/min) }\end{array}$ & $\begin{array}{c}\mathrm{ACR} \\
\left(\mathrm{V}_{3} / \mathrm{V}_{2}\right)\end{array}$ & $\begin{array}{c}\text { RCR } \\
\left(\mathrm{V}_{3} / \mathrm{V}_{4}\right)\end{array}$ & $\begin{array}{l}\text { Cuefficient of } \\
\text { phosphorylation } \\
\text { (ADP/O) }\end{array}$ \\
\hline Control & $12.2 \pm 1.8$ & $35 \cdot 7 \pm 4 \cdot 3$ & $140.9 \pm 10.7$ & $320 \pm 3 \cdot 6$ & $4.05 \pm 0.19$ & $4 \cdot 55 \pm 0 \cdot 31$ & $1.86 \pm 0.08$ \\
\hline Diabetes & $91 \pm 1.4$ & $35 \cdot 0 \pm 2 \cdot 5$ & $107.4 \pm 7.6^{*}$ & $33 \cdot 5 \pm 4 \cdot 0$ & $309 \pm 0 \cdot 13^{\dagger}$ & $3 \cdot 32 \pm 0.2^{+}$ & $1.8 \pm 0.1$ \\
\hline Diabetes + melatonin & $11 \cdot 2 \pm 1 \cdot 5$ & $31 \cdot 6 \pm 3 \cdot 4$ & $134.8 \pm 4.9^{\ddagger}$ & $2814 \pm 2 \cdot 0^{\S}$ & $4.46 \pm 0.39^{\S}$ & $4.91 \pm 0.36^{\S}$ & $1.86 \pm 0.07$ \\
\hline
\end{tabular}

Data, presented as a mean $\pm S E M$, represent values at the termination of the experiment (30 days of experimental diabetes).

${ }^{*} p<0.05$ versus the control nontreated animals;

${ }_{p} p<0.01$ versus the control nontreated animals;

$p<0.05$ versus the diabetic group;

$s_{p<0} ;$ versus the diabetic group. 
Table 3. Parameters of oxidative phosphorylation processes in rat liver mitochondria oxidizing glutamate under STZ-induced diabetes (30days). Etfect of melatonin administration $\left(10 \mathrm{mg} \cdot \mathrm{kg}^{-1}\right.$ body weight, 30 days daily).

\begin{tabular}{|c|c|c|c|c|c|c|c|}
\hline & $\begin{array}{c}\text { Basal respiration } \\
\text { rate } \mathrm{V}_{\mathrm{l}} \text {, (ng atom } \\
\mathrm{O} / \mathrm{min} \text { ) }\end{array}$ & $\begin{array}{l}\text { Substrate-dependent } \\
\text { respiration rate } \\
\left.\mathrm{V}_{2} \text {, (ng atom } \mathrm{O} / \mathrm{min}\right)\end{array}$ & $\begin{array}{l}\text { ADP-stimulated } \\
\text { respiration rate } \mathrm{V}_{3} \text {, } \\
\text { (ng atom } \mathrm{O} / \mathrm{min} \text { ) }\end{array}$ & $\begin{array}{c}\text { Respiration rate } \\
\text { after } \mathrm{ADP} \text {-consumption } \\
\left.\mathrm{V}_{4} \text {, (ng atom } \mathrm{O} / \mathrm{min}\right)\end{array}$ & $\begin{array}{c}\mathrm{ACR} \\
\left(\mathrm{V}_{3} / \mathrm{V}_{2}\right) \\
\end{array}$ & $\begin{array}{c}\text { RCR } \\
\left(V_{3} / V_{4}\right)\end{array}$ & $\begin{array}{c}\text { Coefficient of } \\
\text { phosphorylation } \\
\text { (ADP/O) }\end{array}$ \\
\hline Contro & $1 \cdot 1 \cdot 2: t 2 \cdot 1$ & $25.1 \pm 2 \cdot 2$ & $104 \cdot 1 \pm 12 \cdot 2$ & $17 \cdot 3 \pm 3 \cdot 4$ & $4 \cdot 14 \pm 0 \cdot 32$ & $6.65 \pm 0.76$ & $2 \cdot 3$ \\
\hline Diabetes & $12 \cdot 0 \pm 1 \cdot 4$ & $20 \cdot 5 \pm 1 \cdot 1^{*}$ & $66.0 \pm 4.9 *$ & $18 \cdot 8 \pm 3 \cdot 1$ & $3.25 \pm 0.25^{*}$ & $4.01 \pm 0.53^{*}$ & $2.24 \pm 0.09$ \\
\hline Diabetes + melatonin & $11.7 \pm 1.5$ & $18.6 \pm 2.4$ & $90.6 \pm 4.9^{\ddagger}$ & $16 \cdot 1 \pm 1.9$ & $5 \cdot 26 \pm 0.65^{\dagger}$ & $5.84 \pm 0.54^{\dagger}$ & $2 \cdot 6 \pm 0.1^{\dagger}$ \\
\hline
\end{tabular}

Data, $r$. esented as a mean \pm SEM, represent values at the termination of the experiment ( 30 days of experimental diabetes).

$* p<0$ U 5 versus the control nontreated animals;

${ }_{p}^{+} p<0.05$ versus the diabetic group:

$\ddagger_{p}<0.01$ versus the diabetic group.

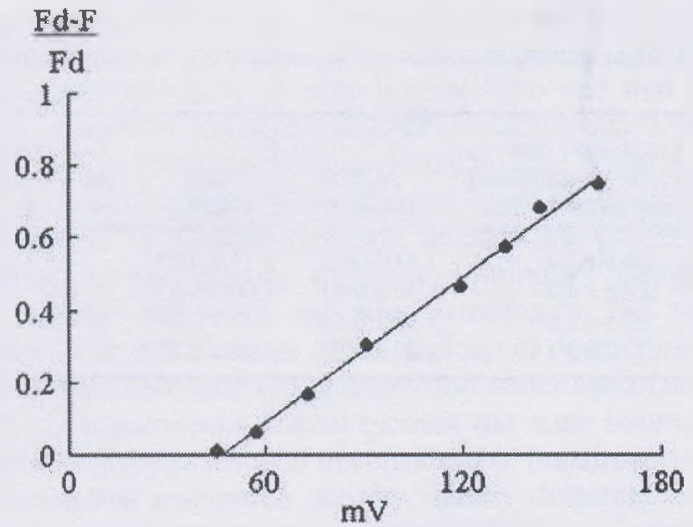

Figure '. Dependence of the intensity of safranin $O$ incorporated into the rat liver mitochondria on the mitochondrial membrane diffusion $\mathrm{K}^{+}$ potential measured in the following medium: $200 \mathrm{mmol} \cdot \mathrm{l}^{-1}$ of sucrose, 20 mmol. $1^{-1}$ of Tris- $\mathrm{HCl}, 1 \mathrm{mmol} \cdot \mathrm{I}^{-1}$ of EDTA, $\mathrm{pH} 7 \cdot 2$, supplemented with $8 \mu$ $\mathrm{mol} \cdot \mathrm{l}^{-1}$ of safranin $0,5 \mathrm{mmol} \cdot \mathrm{l}^{-1}$ of succinate, $0.28 \mu \mathrm{mol} \cdot \mathrm{l}^{-1}$ of valinomycine. $F$, dye Huorescence intensity in the mitochondrial suspension; $F_{d}$, dye fluorescence intensity in the mitochondrial suspension in the presence of 2,4-dinitrophenol $\left(36 \mu \mathrm{mol} \cdot \mathrm{I}^{-1}\right)$. [ $\left.\mathrm{K}_{\text {our }}^{+}\right]$was changed from 0 to $20 \mathrm{mmol} \cdot 1^{-1}$. Protein concentration- $0.3 \mathrm{mg} \cdot \mathrm{ml}^{-1}$

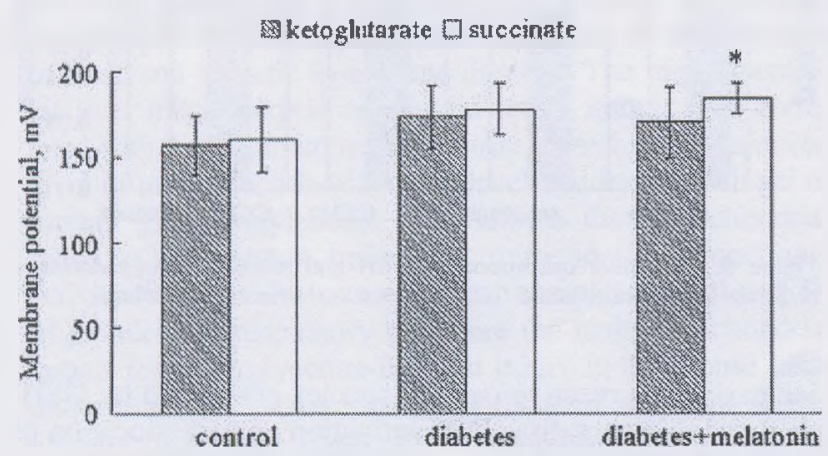

Figure 2. Rat liver mitochondrial membrane potential under cliabetes. Effect of melatonin. Potential was measured by fluorescence of the cationic dye safranin $\mathrm{O}$ incorporated into the mitochondria

not for succinate-dependent respiration (Figure 4). For both substrates, we did not observe membrane potential changes after melatonin administration to the control animals. Rat

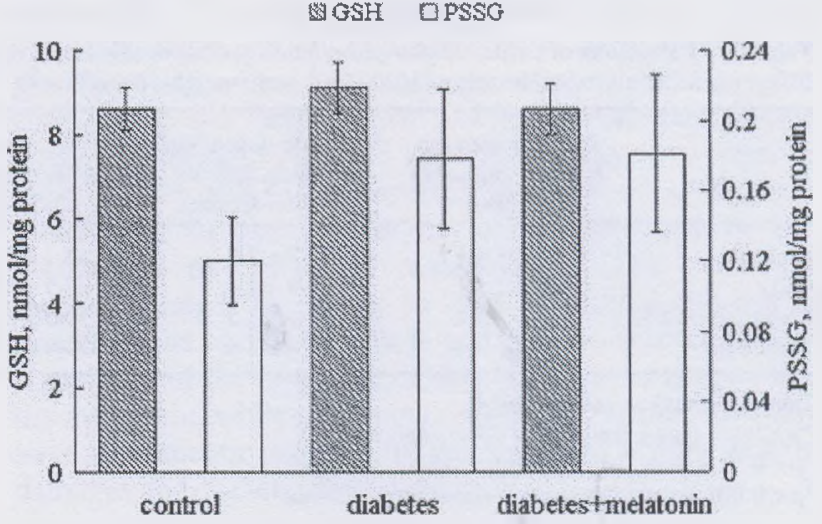

Figure 3. Rat liver mitochondrial GSH and mixed protein-glutathione disulfide levels under diabetes. Effect of melatonin

intoxication under melatonin administration diminished the membrane potential generated by glutamate-dependent respiration by $45 \%(p<0-05)$ and the membrane potential generated by succinate-dependent respiration by $20 \%$ (Figure 4). One can suggest interaction of melatonin with complex I of the mitochondrial respiration chain.

The fundamental impairments in the mitochondria under intoxication were associated with the oxidation of intramitochondrial GSH by $25 \%(p<0.05)$ and the increased level of mixed disulfides of glutathione with intramitochondrial proteins (Figure 5). The melatonin administration in a close of $10 \mathrm{mg} \cdot \mathrm{kg}^{-1}$ to the control animals increased the rates of the glutamate-dependent respiration $\mathrm{V}_{2}$ by $60 \%(p<0.05)$, $\mathrm{V}_{3}$ by $15 \%$ and $\mathrm{V}_{4}$ by $45 \%(p<0.05)$ (Table 5$)$ but did not influence the parameters of succinate-dependent respiration. At the same time, the melatonin administration to intoxicated rats led to an increase in the rate of succinatedependent respiration coupled with phosphorylation $\left(V_{3}\right)$ by $30 \%(p<0.05)$ in comparison with that for mitochondria from intoxicated animals (Table 4).

\section{DISCUSSION}

Results of many studies suggest a role of oxidative stress (high levels of free radicals and a simultaneous decline of 
Table 4. Parameters of oxidative phosphorylation processes in rat liver mitochondria oxidizing succinate after $24 \mathrm{~h}$ of acute $\mathrm{CCl}{ }_{4}\left(4 \mathrm{~g} \cdot \mathrm{kg}^{-1}\right.$ body weight, i.g.). Effect of melatonin administration $\left(10 \mathrm{mg} \cdot \mathrm{kg}^{-1}\right.$ body weight, three times).

\begin{tabular}{|c|c|c|c|c|c|c|c|}
\hline & $\begin{array}{l}\text { Basal respiration } \\
\text { rate } \mathrm{V}_{1},(\mathrm{ng} \text { atom } \\
\mathrm{O} / \mathrm{min}))\end{array}$ & $\begin{array}{l}\text { Substrate-dependent } \\
\text { respiration rate } \mathrm{V}_{2} \text {, } \\
\text { (ng atom } \mathrm{O} / \mathrm{min} \text { ) }\end{array}$ & $\begin{array}{l}\text { ADP-stimulated } \\
\text { respiration rate } \mathrm{V}_{3} \text {, } \\
\text { (ng atom } \mathrm{O} / \mathrm{min} \text { ) }\end{array}$ & $\begin{array}{c}\text { Respiration rate } \\
\text { after ADP-consumption } \\
\mathrm{V}_{4} \text {, (ng atom O/min) }\end{array}$ & $\begin{array}{c}\mathrm{ACR} \\
\left(\mathrm{V}_{3} / \mathrm{V}_{2}\right)\end{array}$ & $\begin{array}{c}\text { RCR } \\
\left(\mathrm{V}_{3} / \mathrm{V}_{4}\right)\end{array}$ & $\begin{array}{c}\text { Coefficient of } \\
\text { phosphorylation } \\
(\mathrm{ADP} / \mathrm{O})\end{array}$ \\
\hline Control & $15 \cdot 7 \pm 3 \cdot 4$ & $47 \cdot 8 \pm 5 \cdot 3$ & $153.9 \pm 11.2$ & $49 \cdot 9 \pm 5 \cdot 3$ & $3 \cdot 20 \pm 0 \cdot 40^{\circ}$ & $3 \cdot 13 \pm 0 \cdot 30$ & $1.64 \pm 0.1$ \\
\hline $\mathrm{CCl}_{4}$ & $11 \cdot 1 \pm 4 \cdot 8$ & $61 \cdot 6 \pm 4 \cdot 6$ & $54 \cdot 2 \pm 3 \cdot 6^{\frac{7}{4}}$ & $584 \div 4.2$ & $1.00 \pm 0 \cdot 12^{\ddagger}$ & $1.10=010118^{1}$ & 00 \\
\hline Melatonin $+\mathrm{CCl}_{4}$ & $10 \cdot 9 \pm 2 \cdot 1^{*}$ & $60 \cdot 2 \pm 4 \cdot 8$ & $71.9 \pm 50^{1 \$}$ & $60 \cdot 4+4 \cdot 6$ & $1.13 \pm 0.13^{\ddagger}$ & $1-18 \pm 0 \cdot 14^{\ddagger}$ & 00 \\
\hline Melatonin & $13 \cdot 6 \pm 24$ & $53 \cdot 6 \pm 6 \cdot 7$ & $141.4 \pm 15.4$ & $45 \cdot 9 \pm 4 \cdot 8$ & $2 \cdot 6 \pm 0 \cdot 3$ & $3.03 \pm 0.40$ & $1.48 \pm 0.2$ \\
\hline
\end{tabular}

Data presented as inean \pm SEM

${ }^{*} p<0.05$ versus the control nontreated animals;

$p<0.01$ versus the control nontreated animals;

${ }^{\ddagger} p<0.001$ versus the control nontreated animals;

${ }_{s} p<0.05$ versus the $\mathrm{CCl}_{4}$-intoxicated animals.

Table 5. Parameters of oxidative phosphorylation processes in rat liver mitochondria oxidizing glutamate after $24 \mathrm{~h}$ of acute $\mathrm{CCl}_{4}$ ( $4 \mathrm{~g} \cdot \mathrm{kg}$ body weight, i.g.). Effect of melatonin administration $\left(10 \mathrm{mg} \cdot \mathrm{kg}^{-1}\right.$ body weight, three times).

\begin{tabular}{|c|c|c|c|c|c|c|c|}
\hline & $\begin{array}{l}\text { Basal respiration } \\
\text { rate } \mathrm{V}_{1} \text {, (ng atom } \\
\mathrm{O} / \mathrm{min}) \text { ) }\end{array}$ & $\begin{array}{l}\text { Substrate-dependent } \\
\text { respiration rate } \mathrm{V}_{2} \text {, } \\
\text { (ng atom } \mathrm{O} / \mathrm{min} \text { ) }\end{array}$ & $\begin{array}{l}\text { ADP-stimulated } \\
\text { respiration rate } \mathrm{V}_{3} \text {, } \\
\text { (ng atom } \mathrm{O} / \text { min })\end{array}$ & $\begin{array}{c}\text { Respiration rate } \\
\text { after } A D P-c o n s u m p t i o n \\
\left.V_{4} \text {, (ng atom } O / \mathrm{min}\right)\end{array}$ & $\begin{array}{c}\mathrm{ACR} \\
\left(\mathrm{V}_{3} / \mathrm{N}_{2}\right)\end{array}$ & $\begin{array}{c}\text { RCR } \\
\left(\mathrm{V}_{3} / \mathrm{V}_{4}\right)\end{array}$ & $\begin{array}{c}\text { Coefficient of } \\
\text { phosphorylation } \\
(\mathrm{ADP} / \mathrm{O})\end{array}$ \\
\hline Control & $14 \cdot 3 \pm 4 \cdot 1$ & $18 \cdot 7 \pm 2.3$ & $63 \cdot 1 \pm 4 \cdot 7$ & $20 \cdot 6 \pm 2.2$ & $3 \cdot 41 \pm 0 \cdot 32$ & $3.11 \pm 0.29$ & $1 \cdot 6 \pm 0.1$ \\
\hline $\mathrm{CCl}_{4}$ & $10 \cdot 6 \pm 3.1$ & $20.8 \pm 4.6$ & $27.5 \pm 4.2^{\dagger}$ & $27.5 \pm 4.2$ & $1.36 \pm 0.51^{\dagger}$ & $1.00 \pm 0.02^{\ddagger}$ & 00 \\
\hline Melatonin $+\mathrm{CCl}_{4}$ & $13 \cdot 6 \pm 3 \cdot 1$ & $21-1 \pm 3.5$ & $29 \cdot 5 \pm 3 \cdot 7^{\dagger}$ & $26 \cdot 5 \pm 2 \cdot 8$ & $1.39 \pm 0.53^{*}$ & $1.11 \pm 0.09^{t}$ & 0.0 \\
\hline Melatonin & $15.9 \pm 3.4$ & $33 \cdot 0 \div 3 \cdot 6^{*}$ & $73 \cdot 4 \pm 7 \cdot 7$ & $30 \cdot 4 \pm 3 \cdot 3 *$ & $2 \cdot 23 \pm 0.22$ & $2.41 \pm(1) .22$ & $1.7 \pm 0.2$ \\
\hline
\end{tabular}

Data presented as mean \pm SEM.

${ }^{*} p<0.05$ versus the control nontreated animals;

$p<0.01$ versus the control nontreated animals;

$t_{p}<0.001$ versus the control nontreated animals.

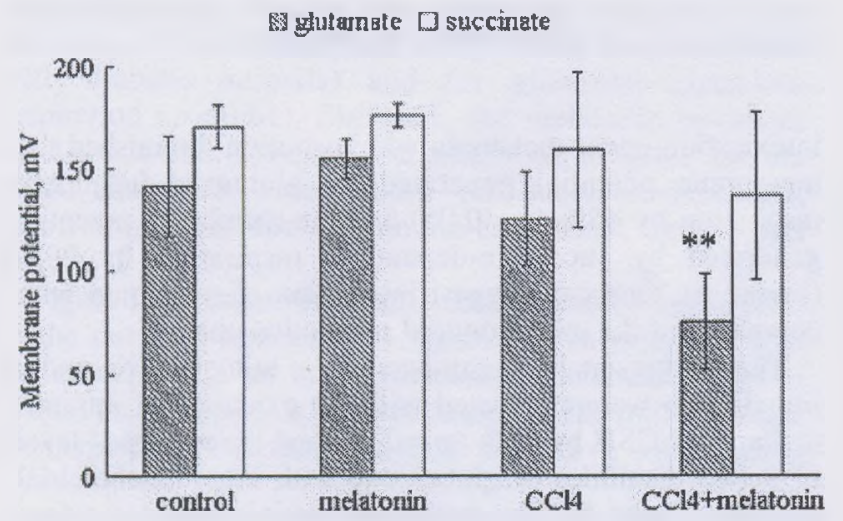

Figure 4. Rat liver mitochondrial membrane potential under acute $\mathrm{CCl}_{4}$ intoxicution. Effect of melatonin. Potential was measured by fluorescence of the cationic dye safranin $O$ incorporated into the mitochondria

antioxidant defense mechanisms) in the development of insulin resistance, diabetes and diabetic complications, and evidence for a protective effect of antioxidants. ${ }^{21,30} \mathrm{An}$ elevated membrane electrochemical potential $\Delta \mu_{\mathrm{H}+}$ favors mitochondrial free radical production, and limiting the magnitude of this potential under State 4 conditions should decrease free radical production. ${ }^{33}$ Reactive oxygen species interfere with insulin signalling and inhibit the translocation of glucose transporter GLUT4 in the plasma membrane. ${ }^{30}$ By the same way, intoxication by acetaminophen resulted in

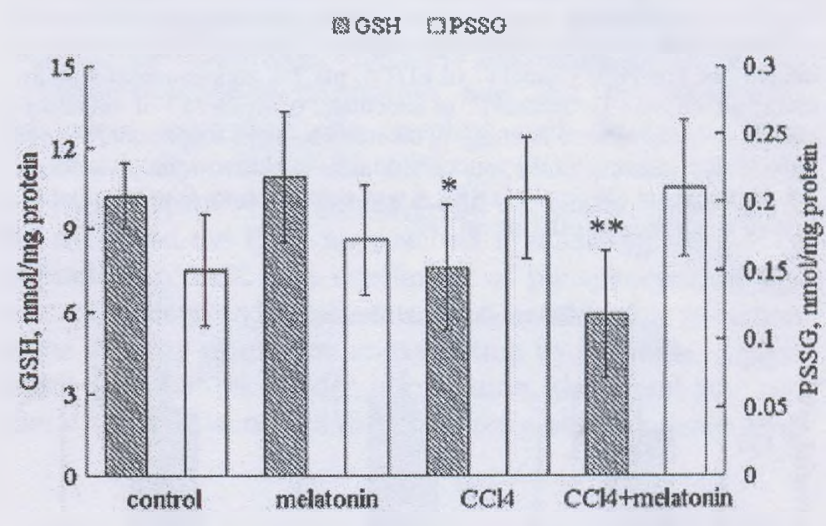

Figure 5. Rat liver mitochondrial GSH and mixed protein-glutathione disulfide levels under acute $\mathrm{CCl}_{4}$ intoxication. Effect of melatonin

increasing the reactive oxygen species generation by GSHdepleted mitochondria, JNK activation and translocation of activated JNK to the mitochondria where JNK induces mitochondrial permeability transition and inhibits mitochondria bioenergetics. ${ }^{12}$ It was shown that enhanced oxidative stress caused by diabetes is accepted to lead to endothelial dysfunction, and melatonin treatment $\left(10 \mathrm{mg} \cdot \mathrm{kg}^{-1}\right.$ i.p. for 8 weeks) protected the contractile functions of the aorta and the corpus cavernosum and prevented the oxidative stress under diabetes. ${ }^{27}$ Similarly, melatonin administration for 15 days 
$\left(200 \mu \mathrm{g} \cdot \mathrm{kg}^{-1}\right.$ i.p.) effectively normalized the impaired antioxidant status in STZ-induced diabetes ${ }^{4}$ and may be useful in delaying the complicated effects of diabetes. Strategies to decrease mitochondrial radical production and oxidative damage may have a therapeutic potential. It has recently been shown that melatonin $\left(10 \mathrm{mg} \cdot \mathrm{kg}^{-1}\right)$ improves methanol intoxication-induced oxidative liver injury in rats, preventing reduction in all antioxidant enzyme activities, decreasing significantly the levels of malondialdehyde and protein carbonylation, as well as necrosis and portal inflammation. ${ }^{16}$ In our earlier experiments, the melatonin administration prevented structural and functional liver damage under $\mathrm{CCl}_{4}$ intoxication ${ }^{38}$ but did not cause a pronounced recovery of the mitochondrial functional activity. ${ }^{20}$ Recently, close relationships have been found between insulin, the endocrine system and melatonin. ${ }^{28}$ Peschke showed that melatonin influenced insulin secretion both in vivo and in vitro and that these effec $_{\text {.. were }}$ MT(1)-receptor and MT(2)-receptor mediated. ${ }^{28}$ Melatonin $\left(10 \mathrm{mg} \cdot \mathrm{kg}^{-1}\right)$ can increase the activities of mitochondrial respiratory complexes I and IV after its administration in a time-dependent manner and prevented a decrease in the activity of these respiratory complexes incluced by ruthenium red administration. ${ }^{22}$ The results suggest that melatonin in pharmacological doses protected against oxidative stress in diabetes and under intoxication.

In our experimental animal models, the acute intoxication as well as diabetes resulted in considerable impairment of the mitochondrial respiration activity. Under diabetes, we observed a pronounced decrease of the ADP-stimulated oxygen consumption $V_{3}$, as well as the acceptor and respiration control ratios without an appreciable change in the ADP/O ratio. In comparison, under intoxication. we found that the respiration rate, $V_{3}$, and the phosphorylation coefficient considerably decreased, and the RCR and the ACR diminished, approaching 1, which indicates uncoupling of the oxidation and phosphorylation processes and loss of respiration control. At the same time, the mitochondrial membrane poter ial under intoxication and diabetes did not change significantly. Mitochondrial dysfinction may be the first sign of toxic and diabetic liver tissue damage. The impairment of rat liver mitochondrial respiration under intoxication correlated with the disturbed mitochondrial redox balance (reduced level of intramitochondrial GSH level and increased level of protein glutathionylation). It is known that mitochondrial redox (GSH) status modulates mitochondrial functional activity. ${ }^{26}$ It was shown earlier that complexes I, III and IV of the electron respiratory chain are the main mitochondrial targets for hyperglycemia-induced injury in the mouse heart under diabetes. ${ }^{3}$ Two months of diabetes were not shown to alter the renal cortical mitochondrial respiration. In contrast, 12 months of diabetes caused a significant inhibition of State 3 respiratory activity and an increase of respiratory activity in State $4 .^{31}$ The investigation of a possible functional defect in cardiac mitochondria from diabetic rats indicates a decline in State 3 respiration only in animals having a marked decrease in body weight; heart mitochondria from hyperglycemic rats showed an increase in State 4 glutamatedependent oxygen consumption. ${ }^{17}$ Four-week and 9-week diabetes did not substantially affect the brain mitochondrial function. 25

The direct inhibition of the respiration chain enzyme complexes and damage of mitochondrial membrane may be signs of the mitochondrial dysfunction in diabetes and under intoxication. Meanwhile, there are different molecular mechanism(s) and different targets of mitochondrial damage in diabetes and under intoxication. The melatonin administration in a pharmacological dose affected the mitochondrial function and prevented mitochondrial dysfunction, demonstrating mitochondria-specific activity. Under diabetes, melatonin reversed the decreased succinate-dependent and glutamate-dependent respiration $\mathrm{V}_{3}$ rates and the ACR and RCR. Under intoxication, the pharmacological dose of melatonin $\left(10 \mathrm{mg} \cdot \mathrm{kg}^{-1}\right)$ induced some increase of the succinate-dependent $V_{3}$ rate and further dissipation of the glutamate-dependent membrane potential of rat liver mitochondria. It has been shown that melatonin may recycle NADH by electron donation and, by this way, may improve the efficiency of NADH as an energy carrier and antioxidant. Interactions between melatonin and $\mathrm{NADH}$ may be implicated in mitochondrial metabolism. ${ }^{36}$ The effects of melatonin might be caused by both its radical scavenging properties, its metabolic effects and specific interaction with complexes of the respiratory chain. Our results suggest that the melatonin, while regulating mitochondrial function, may have a therapeutic potential for the correction of diabelic liver damages and diabetic complications.

\section{CONFLICT OF INTEREST}

The authors have declared that there is no conflict of interest.

\section{REFERENCES}

1. Acuña-Castroviejo D, Martín M, Macias M, Escames G, Leó J, Khaldy H, Reiter RJ. Melatonin, mitochondria, and cellular bioenergetics. J Pineal Res 2001; 30: 65-74.

2. Akerman KE, Wikstrom KF. Safranine as a probe of the mituchondrial membrane potential. FEBS Let1 1976; 68: 191-197.

3. Allegra M, Reiter RJ. Tan DX, Gentile C, Tesoriere L, Livrea MA. The chemistry of melatonin's interaction with reactive species. $J$ Pineal Res 2003; 34: 1-10.

4. Anwar MM, Meki A-RMA. Oxidative stress in streptozotocin-induced diabetic rats: effects of garlic oil and melatonin. Comp Biochem Physiol Part A 2003; 135: 539-547.

5. Brzezinski A. Melatonin in humans. N Engl J Med 1997; 336: 186-195.

6. Chance B, Williams G. Respiratory enzymes in oxidative phosphorylation. III. The steady state. J Biol Chem 1955; 217: 383-393.

7. Dremza IK, Lapshina EA, Kujawa J, Zavodnik IB. Oxygen-related processes in red blood cells exposed to tert-butyl hydroperoxide. Redox Rep 2006; 11: 185-192.

8. Duchen MR. Mitochondria in health and disease: perspectives on a new mitochondrial biology. Mol Aspects Med 2004; 25: 365-451.

9. Ellman G. Tissue sulfhydryl groups. Arch Biochem. Biophys 1959; 82: $70-77$.

10. Fosslien E. Mitochondrial medicine - molecular pathology of defective oxidative phosphorylation. Ann Clin Lab Sci 2001; 31: 25-67.

11. Green K, Brand MD, Murphy MP. Prevention of mitochondrial oxidative damage as a therapeutic strategy in diabetes. Diabefes 2004; 53: $\$ 110-S 118$.

12. Hanawa N, Shinohara M, Saberi B, Gaarde WA, Han D, Kaplowitz N. Role of JNK translocation to mitochondria leading to inhibition of 
mitochondria bioenergetics in acetaminophen-induced liver injury. $J$ Biol Chem 2008; 283: 13565-13577.

13. James AM, Murphy MP. How mitochondrial damage affects cell function. J Biomed Sci 2002; 9: 475-487.

14. Johnson D, Lardy HA. Isolation of liver or kidney mitochondria. In Methods in Enzymology. Estabrook R, Pullmam ME (eds.). V, 10; Academic Press: London NY, 1967; 94-96.

15. Krahenbuhl L, Ledermann M, Lang C, Krahenbuhl S. Relationship between hepatic mitochondrial functions in vivo and in vitro in rats with carbon tetrachloride-induced liver cirrhosis. J Hepatol 2000; 33: 216-223.

16. Kurcer Z, Oguz E, Iraz M, Fadillioglu E, Baba F, Koksal M, Olmez E. Melatonin improves methanol intoxication-induced oxidative liver injury in rats. J Pineal Res 2007; 43: 42-49.

17. I hin O. Rumani A. Mitochondria respiration and susceptibility to ischemia-repertusion injury in diabetic hearts. Arch Biochem Biophys 2003: 420: $298-304$

18. Lowry $\mathrm{OH}$, Rosebrough NJ, Farr AL. Randall RJ. Protein measurement with the Folin phenol reagent. J Biol Chem 1951; 193: 265-275.

19. Mahal HS, Sharma HS, Mukherjee T. Antioxidant properties of melatonin: a pulse radiolysis study. Free Radical Biol Med 1999; 26: 557-565.

20. Maksimchik YZ, Dremza JK, Lapshina EA, Cheshchevik VT, Sudnikovich EJ, Zabrodskaya SV, Zavodnik IB. Rat liver mitochondria impairments under acute carbon tetrachloride-induced intoxication. Effects of melatonin. Biochem (Moscow) Suppl Ser A: Membr Cell Biology 2010; 4: 187-195.

21. Maritim AC, Sanders RA, Watkins JB, 3rd. Diabetes, oxidative stress, and antioxidants: a review. J Biochem Mol Toxicol 2003; 17: $24-38$.

22. Martín M, Macías M, Escames G, Reiter RJ, Agapito MT, Ortiz GG, Acuña-Castroviejo D. Melatonin-induced increased activity of the respiratory chain complexes I and IV can prevent mitochondrial damage induced by ruthenium red in vivo. J Pineal Res 2000; 28 : $242-248$.

23. Marshall KA, Reiter RJ, Poeggeler B, Aruoma OI, Halliwell B. Evaluation of the antioxidant activity of melatonin in vitro. Free Radic Biol Med 1996; 21: 307-315.

24. $\mathrm{N}$ ore $\mathrm{AL}$, Bonner $\mathrm{WD}$. Measurements of membrane potentials in plant mitochondria with the safranine method. Plant Physiol 1982; 70: $1271-1276$.

25. Moreira PI, Santos MS, Moreno AM, Proenca T, Seica R, Oliveira CR. Effect of streptozotocin-induced diabetes on rat brain mitochondria. $J$ Neuroendocrinol $2004 ; 16: 32-38$.

26. Nultun-Persson AC, Starke DW, Mieyal JJ, Szweda LI. Reversible inactivation of alpha-ketoglutarate dehydrogenase in responses to alterations in the mitochondrial glutathione status. Biochemistrv 2003; 42: 4235-4242.

27. Paskaloglu K, Sener G, Ayangolu-Dulger G. Melatunin treatment protects against diabetes-induced functional and biochemical changes in the rat aorta and corpus cavernosum. Eur $J$ Pharmacol 2004; 499: 345-354.

28. Peschke E, Wolgast S, Bazwinsky* I, Ponicke K, Muhlbauer E. Increased melatonin synthesis in pineal glands of tats in streptozotocin induced type 1 diabetes. J Pineal Res 2008; 45: 439-448.

29. Poeggeler B, Reiter RJ, Hardeland L. Melatonin and structurally related, endogenous indoles act as potent electron donors and radical scavengers in vitro. Redox Rep 1996: 2: 179-184.

30. Rosen P, Nawroth PP, King G, Moller W. Tritschler HJ, Packer L. The role of oxidative stress in the onset and progression of diabetes and its complications: a summary of a Cungress Series sponsored by UNESCO-MCBN, the American Diabetes Association and the German Diabetes Society. Diabetes Metab Res Rev 2001; 17 : $184-212$.

31. Rosca MG, Mustata TG, Kinter MT, Ozdemir AM, Kern TS, Szweda LI, Brownlee M, Monnier VM, Weiss MF. Glycation of mitochondrial proteins from diabetic rat kidney is associated with excess superoxide formation. Am J Physiol Renal Physiol 2005; 289: 420-430.

32. Rossi R, Cardaioli E, Scaloni A, Amiconi G, Di Simplicio P. Thiol groups in proteins as endogenous reductants to determine glutathioneprotein mixed disulphides in biological systems. Biochim Biophys Acta 1993; 1164: 289-298.

33. Skulachev VP. Role of uncoupled and non-coupled oxidations in maintenance of safely low levels of oxygen and its one-electron reductants. $Q$ Rev Biophys 1996; 29: 169-202.

34. Smith RAG, Porteous CM, Gane AM, Murphy MP. Delivery of bioactive molecules to mitochondria in vivo. Proc Natl Acad Sci USA 2003; 100: 5407-5412.

35. Sudnikovich EJ, Maksimchik YZ, Zabrodskaya SV, Kubyshin VL, Lapshina EA, Bryszewská M, Reiter RJ, Zavodnik IB. Melatonin attenuates metabolic disorders due to streptozotocin-induced diabetes in rats. Eur J Pharmacol 2007; 569: 180-187.

36. Tan DX, Manchester LC, Sainz RM, Mayo JC, Leon J, Hardeland R, Poeggeler B, Reiter RJ. Interactions between melatonin and nicotinamide nucleotide: NADH preservation in cells and in cell-free systems by melatonin. J Pineai Res 2005; 39: 185-194.

37. Turko I, Li L, Kulwant S, Stuehr D, Chang J. Protein tyrosine nitration in the mitochondria from diabetic mouse heart. $J$ Biol Chem 2003; 278: $33972-33977$.

38. Zavodnik LB, Zavodnik IB, Lapshina EA, Belonovskaya EB, Martinchik DI, Kravchuk RI, Bryszewska M, Reiter RJ. Protective effects of melatonin against carbon tetrachloride hepatotoxicity in rats. Cell Biochem Funct 2005; 23: 353-359. 